DOI: https://doi.org/10.47405/aswj.v6i6.192

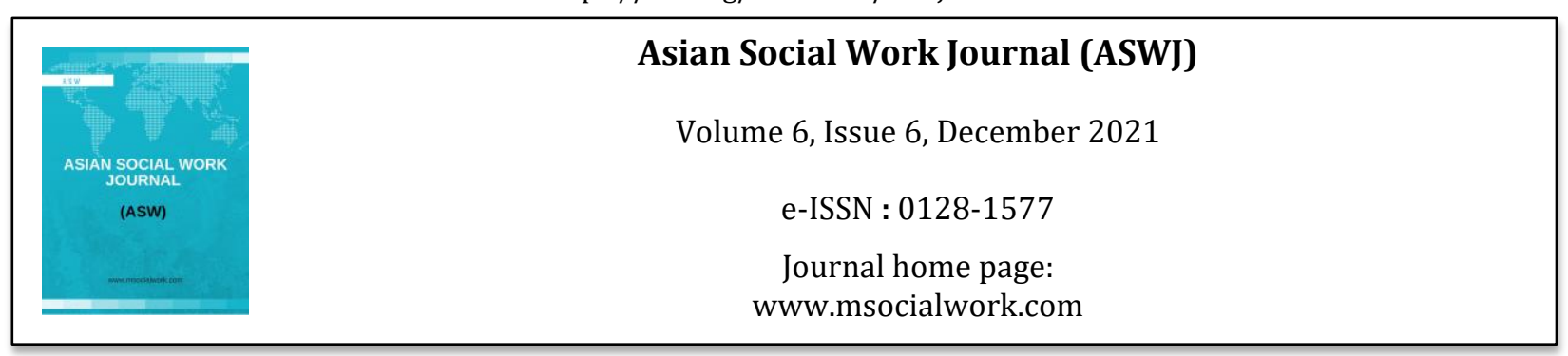

\title{
Social Rehabilitation for Vagrants and Beggars Through Institutional Approach in Indonesia
}

\author{
Yanuar Farida Wismayanti' ${ }^{1}$, Husmiati Yusuf ${ }^{1}$, Alit Kurniasari ${ }^{1}$, Aulia Rahman'1 ${ }^{1}$ Mery Ganti ${ }^{1}$, \\ Widiarto', Hari Harjanto Setiawan', Badrun Susantyo1, Ita Konita1, Delfirman', \\ Muhammad Belanawane ${ }^{1}$ \\ ${ }^{1}$ Center Research and Development of Social Welfare, Ministry of Social Affairs, Republic of Indonesia
}

Correspondence: Yanuar Farida Wismayanti (yanuarwismayanti@gmail.com)

\begin{abstract}
The problem of vagrants and beggars is a fairly complex issue in big cities such as Jakarta, Bandung, Semarang, Surabaya, Medan, and Makassar. These big cities' charms have attracted the poor with low education levels and limited access to education, health, and skill development. Many service programs for the vagrants and beggars have been carried out, yet the problems related to the vagrants and beggars have never subsided. Quantitative and qualitative approach are used to determine how the condition of social rehabilitation services carried out for vagrants and beggars by the government and the community, the extent of their level of social functioning, and the role of social workers in social rehabilitation services. A population sample is a group of vagrant and beggars who receive social services in government institutions and community organisation. The sampling used was the probability sampling method with a sample of 487 respondents in the six provinces, namely DKI Jakarta, West Java, East Java, Central Java, North Sumatra, and South Sulawesi. Thus, interview the stakeholders who related on social rehabilitation program for vagrants and beggars are examined in qualitative approach. This research found that in the process of social rehabilitation services for vagrants and beggars, there are still differences in the service standards between institutions; limitations in human resources, including social workers; limited budget support; limited cooperation, and coordination between local government organizations at the provincial, regency/municipal, and central government along with related stakeholders. It conclude that the national policy platform related to the handling of vagrants and beggars needs to be the focus to overcome the complexity of the problems faced by this marginal group.
\end{abstract}

Keywords: social rehabilitation services, marginalized groups, homeless and beggars

\section{Introduction}

The phenomenon of vagrants and beggars is a social problem that must be taken seriously. Mainly due to the existence of vagrants and beggars in urban areas has shown contradictory situations and conditions like two sides of a coin; development and social problems. The central and local governments have tried to reduce the number of vagrants with various programs such as providing counseling, skill development, supervision, and further coaching. In addition, the government is also trying to build housing for them, such as Rusunawa (simple flat buildings) and hold transmigration program (moving residents to other islands that still hold plenty of lands to cultivate) (Lastiwi \& Badruesham, 2017). 


\section{Asian Social Work Journal (ASWJ), Volume 6, Issue 6, (page 13 - 23), 2021 \\ DOI: https://doi.org/10.47405/aswj.v6i6.192}

Many service programs for vagrants and beggars are actualized. However, various problems related to the vagrants and beggars have never subsided, especially in big cities, such as Jakarta, Surabaya, Semarang, Bandung, Makassar, and others. The existence of vagrants and beggars in big cities will burden the central, provincial and city governments on environmental and social life.

This research is important due to the Indonesian commitment for the SDG's (Sustainable Development Goals) Agenda to end poverty in all its forms everywhere. In addition, the vision of President Joko Widodo's Government that focused on the presence of the Country, building from the Periphery and Mental Revolution is essential to approved that the commitment of government to protect the poorest and vulnerable groups. Government Regulation No. 39 of 2012 concerning the Implementation of Social Welfare mandated social rehabilitation as social welfare program implementation is in the authority of the central and regional governments. It includes social rehabilitation for marginalized groups to accelerate the economic recovery and social reforms contained in the RKP (Government Work Plan) 2021. This program is necessary to develop adaptive social protection schemes, including reaching marginal groups, vagrants, and beggars.

Thus, the role of the Central Government, in this case through the Ministry of Social Affairs in the context of social rehabilitation for vagrants and beggars (through the Centre's and ATENSI Program) should be support by the local governments through social institutions, community participation through community empowerment programs.

Research on Social Rehabilitation Services for Marginalized Groups; The study on Vagrants and Beggars through institutional approach conducted to find out how (1) the condition of social rehabilitation services that have been carried out by the government and by the community and the obstacles faced; (2) the extent to which the level of social functioning of beneficiaries; the vagrants and beggars, is viewed from the dimensions of meeting basic needs, social roles, and independence in fulfilling both social and economical life; and (3) the extent of the role of social workers in the process of social rehabilitation services for vagrants and beggars. The results of this research are expected to be a reference and basis for formulating policies related to social rehabilitation services for marginalised group such as vagrants and beggars.

\section{Literature Review}

Vagrants and beggars are social problems often encountered in big cities. It is undeniable that the more advanced the development, the more the emergence of vagrants and beggars. This problem is due to the increasing needs of people's lives while the available jobs are inadequate (Fitri, 2019). Various factors causing and reasonings for being vagrants were also found in the study of Kuntari and Hikmawati (2017), including economic factors or poverty, geographical constraints in the original regions, and socio-psychological and socio-cultural factors. The relatively large income from begging causes them to be reluctant to pursue other jobs.

According to Merlindha and Hati's (2015) research, social rehabilitation efforts in rehabilitation centers were not maximized. The vagrants in Jakarta tend to return to the streets after receiving guidance at the center. This research provides recommendations to the government to provide homesteads care institutions focused on vagrants and beggars as a social rehabilitation effort and provide strict sanctions to vagrants and beggars who return to the streets.

Indonesian Law Number 14 of 2019 concerning Social Workers Article 1 states that: "Social Functionality is a condition that allows individuals, families, groups, and communities to be able to fulfill their basic needs and rights, carry out their social duties and roles, and overcome problems in their lives." Sukoco (1997) explains that social function is part of a person's ability to carry out life tasks, meet needs, and solve problems; this can be viewed from 3 aspects, namely: (i) social functionality is seen as the ability to carry out social roles; (ii) social functionality is seen as the ability to meet needs; and (iii) social functionality is seen as the ability to solve problems at hand. 


\section{Asian Social Work Journal (ASWJ), Volume 6, Issue 6, (page 13 - 23), 2021 \\ DOI: https://doi.org/10.47405/aswj.v6i6.192}

In social rehabilitation, there are three models of services provided to clients, namely as follows: 1 ) Institutional Based Rehabilitation (IBR), by placing people with problems in a particular institution; 2) Extra-institutional Based Rehabilitation by placing people with problems in their families and communities; and 3) Community Based Rehabilitation (CBR), a model of action carried out at the community level by using its resources and potential (Husmiati et al., 2020).

According to Law Number 9 of 2011 concerning Social Welfare, social rehabilitation is to restore and develop the abilities of a person experiencing social dysfunction so that they can carry out their social functions properly (Article 7). Article 7 paragraph 3 states that social rehabilitation efforts are provided in the form of a) psychosocial motivation and diagnosis; b) care and upbringing; c) vocational training and entrepreneurship development; d) spiritual, mental guidance; e) physical guidance; f) social guidance and psychosocial counseling; g) accessibility services; h) social help and assistance; i) resocialization guidance; j) further guidance, and k) referrals.

Social rehabilitation for vagrants and beggars has goals and functions, including changing their way of life and earning income according to society's prevailing norms and adequately carrying out their functions and social roles in the community.

Zastrow (1996) defines social work as a professional activity to help individuals, groups, and communities improve their ability to function socially and create community conditions that enable them to achieve their goals. In addition, according to Zastrow (2020), social work can be interpreted as an activity of assistance given to individuals, groups, and communities to increase the ability to function socially so that individuals, groups, and communities become independent.

The roles and functions of social workers are strengthened by the issuance of the Social Work Law No. 14 of 2019 concerning Social Workers. The law states that the definition of a social worker is someone who has the knowledge, skills, and values of social work practice and has obtained a certificate of competence (Article 1 paragraph 1). Social worker is a profession that provides professional services to restore the social functioning of individuals, families, groups, and communities, including social rehabilitation services for marginalized groups of vagrants and beggars. Vagrants and beggars often face the stigma of being lazy, unwilling to work, weak mentally, having physical or psychological disabilities (Ahmad, 2010). In addition, there are external factors, including social, cultural, economic, educational, environmental, religious, and geographical factors (Ahmad, 2010). This condition also affects the process of social rehabilitation services.

Indonesian Law Number 23 of 2014 concerning Regional Government describes concurrent government affairs. Concurrent government affairs are part of the Central, Provincial, and Regency/Municipal Governments. This decentralization condition caused gaps in social rehabilitation services for vagrants and beggars.

In social rehabilitation services, institutions' programs and interventions also affect the implementation of services. Anggriana's research (2016) shows that institutionally, social institutions have limited funds to support vagrants' opening a business. Their opportunity to work in the formal sector is challenging; the job skills taught are minimal, generally below the standard of the job market, not to mention the less appropriate mental and social guidance methods. So that institutionally, program interventions also face problems that affect the success of the social rehabilitation service program. Research by Nurdin et al. (2012) found that after-care is vital to implement, considering the service process does not only reach the termination stage. The continuation of the effectiveness of social rehabilitation services within the institution is not known after the beneficiary returns to their home. Further guidance is essential to determine the level of social functioning of the beneficiaries.

\section{Methodology}

This research used a mixed-method approach, which combined quantitative and qualitative methods to obtain more comprehensive information. A quantitative approach was used to determine the extent of 
social rehabilitation services for beneficiaries through the care institutions centers; 2) determine the level of social functioning for vagrant and beggar groups; and 3) identify problems and solutions. A qualitative approach was used to obtain in-depth information about social services provided at the care institutions centers such as Panti/Balai/LKS (home care/residential institution) that focus on social rehabilitation for vagrants and beggars, including triangulation of quantitative data. A population sample is a group of vagrant and beggars who receive social services in government institutions and community organisation. This study uses a probability sampling technique in the form of proportionate stratified random sampling. The population of social rehabilitation services beneficiaries for the vagrants and beggars in the six provinces, namely DKI Jakarta, West Java, East Java, Central Java, North Sumatra, and South Sulawesi, was 3578 people with a sample of 487 respondents with 31 enumerators.

Data collection in this research was done in two phases-The first phase is quantitative research, with the distribution of e-surveys through the Survey Monkey app, conducted for five days from April 30 to May 4, 2021.

The second phase, data form filling by respondents was done through interviews by trained enumerators. For the second stage, this research was carried out with a qualitative approach through in-depth interviews for 21 informants, namely social workers, government staffs and the beneficieries program in the social institutions. The institutions that became the location for collecting qualitative data were the Binjai Gepeng Social Service UPT (North Sumatra); PSBK Harapan Jaya (DKI Jakarta), PSBK Cisarua, Social Rehabilitation Center for Vagrants-Beggars Pangudi Luhur and LKS for the Anti-Drugs and Crime Movement (Gerakan Anti Narkoba dan Kriminalitas or G.A.N.K) Bandung City (West Java); PGOT Mardi Utomo Semarang (Central Java); PSBK Pasuruan and LKS Insan Sejahtera in Malang (East Java); LKS Pabatta Ummi Foundation and LKS Ummi Naharia Foundation (South Sulawesi).

The obtained data collection was analyzed in several stages. The first stage is processing quantitative data for survey results, including editing, coding, and tabulation. Furthermore, the data processing results will be analyzed to obtain descriptive data by examining all data from research instruments, such as documents, notes, FGD results and interviews, recordings, and observations, and analyzed based on a thematic analysis approach.

The research data has not yet reflected the national data, where the population and sample of this study are groups of vagrants and beggars who receive services in institutions and community-based services by Balai/Panti or LKS.

\section{Result and Discussion}

\section{Respondent Profile/Characteristics}

The lives of vagrant beggars, scavengers/displaced persons, or people with socioeconomic vulnerability require intervention to change their lifestyle. They are "forced" to live homeless in big cities with reasons to earn a living, not having a job in their hometown, or other reasons such as facing psychological or family problems that require leaving their homes. They come to big cities without adequate skills and educational background. Generally, only elementary, or junior high school graduates, and most of them are in the productive age group. They come not alone but also bring their spouses and children to live in the big city. This condition makes them can only work in the informal sector or vagrancy because they do not have permanent residence.

These results qualitatively show that the profile of the vagrants and beggars shows that various factors cause this group to be marginalized. This is in line with Fadri's view (2019), among others, because of the poverty level, low education, limited work skills that affect their income level. In addition, vagrants and beggars from urban areas who are not absorbed in the workforce prefer to be beggars with guaranteed cash per day without a special skill (Fadri, 2019; Mar Puji et al., 1990). 
In addition, this group is in a vulnerable and discriminatory condition. Educationally, they have not received proper access, including being vulnerable because they do not have proper housing in big cities like Jakarta, Surabaya, Medan, Bandung, and Semarang. Their children do not go to school, do not have birth certificates, and do not even have ID cards or legal identities, reducing their chances as poor citizens who have the right to social protection. Furthermore, the results of this study also show that some respondents who are beneficiaries of social rehabilitation services for vagrants and beggars in Balai/Panti and LKS do not have Regional Health Coverage (Jamkesda) or other types of health insurance. The results showed that more respondents in care institutions did not have Jamkesda or other health coverage than those who already had. An overview of research respondents is shown in the following infographic.

Table 1: Beneficiary Data by Age Group

\begin{tabular}{ll}
\hline Age Group (years old) & Percentage (\%) \\
\hline$<18$ & $4 \%$ \\
$18-25$ & $10 \%$ \\
$26-33$ & $16 \%$ \\
$34-41$ & $23 \%$ \\
$42-49$ & $23 \%$ \\
$>49$ & $24 \%$ \\
\hline
\end{tabular}

Most respondents are in the productive age range, i.e., between 18-25 years old, of 10\%. Respondents within 26-33 years old are 16\%, 34-41 years old of 23\%, and the $42-49$ years old by $23 \%$. However, some are more than 49 years old, as much as $24 \%$. While those who are children or under 18 years old as much as $4 \%$.

Table 2: Beneficiary Data Based on Recent Education

\begin{tabular}{ll}
\hline Recent Education & Percentage \\
\hline Illiterate & $7 \%$ \\
Didn't Graduated elementary school & $27 \%$ \\
Elementary school graduates & $28 \%$ \\
Junior High & $20 \%$ \\
High school/ Vocational & $16 \%$ \\
Diploma & $2 \%$ \\
\hline
\end{tabular}

The education level of the respondents $28 \%$ are elementary school graduates. The number of respondents who did not finish elementary school also showed a relatively high number of $27 \%, 20 \%$ of junior high school graduates, $16 \%$ of high school/vocational high school graduates, and $2 \%$ of diploma graduates. However, the number of illiterate respondents is still around $7 \%$.

Table 3: Beneficiary Data based on Identity Card Ownership

\begin{tabular}{llll}
\hline ID Card Ownership & No & Yes & Total \\
\hline LKS & $4 \%$ & $51 \%$ & $55 \%$ \\
Panti & $13 \%$ & $32 \%$ & $45 \%$ \\
\hline Total & $17 \%$ & $83 \%$ & $100 \%$ \\
\hline
\end{tabular}

There are still respondents who do not have an identity card in an ID card or National Identification Number (Nomor Induk Kependudukan/NIK). Of the total respondents, about 13\% do not have an identity card, while $4 \%$ of respondents in LKS do not have ID cards and NIK. 
DOI: https://doi.org/10.47405/aswj.v6i6.192

Table 4: Beneficiary Data based on Ownership of Health Coverage/Health Insurance

\begin{tabular}{llll}
\hline Health Insurance Ownership & No & Yes & Total \\
\hline LKS & $21 \%$ & $34 \%$ & $55 \%$ \\
Panti & $29 \%$ & $16 \%$ & $45 \%$ \\
\hline Total & $50 \%$ & $50 \%$ & $100 \%$ \\
\hline
\end{tabular}

Of the total respondents, only $16 \%$ of those in the care institutions have access to health coverage, and $29 \%$ do not yet have access to health insurance. Meanwhile, $34 \%$ of respondents in LKS already have access to health coverage, and $21 \%$ do not have a health coverage beneficiary card.

Table 5: Beneficiary Data by Type/Category

\begin{tabular}{ll}
\hline Beneficiary Category & Percentage \\
\hline Scavengers & $47 \%$ \\
Vagrants and Beggars & $22 \%$ \\
Buskers & $8 \%$ \\
Others & $23 \%$ \\
\hline
\end{tabular}

Regarding the respondents' category, $47 \%$ of all respondents claimed to be scavengers, vagrants, and beggars by $22 \%$, buskers by $8 \%$, and $23 \%$ entered other criteria. Those in the other category stated that they entered care institutions (Balai/Panti/LKS) because they worked as illegal parking attendants. The bank confiscated their houses and worked odd jobs, transvestites, people with mental disorders, or unemployed.

Table 6: Respondents' referral source in the Balai/Panti/LKS

\begin{tabular}{lll}
\hline Referral from & LKS & Panti \\
\hline Social Service & $17 \%$ & $3 \%$ \\
Public figure & $6 \%$ & $16 \%$ \\
Accompanied outreach & $2 \%$ & $38 \%$ \\
Justice Operations & $7 \%$ & $0 \%$ \\
Personal initiative & $11 \%$ & $0 \%$ \\
\hline
\end{tabular}

The results showed that $17 \%$ of respondents in the care institutions were referrals from the Social Service, $11 \%$ came on their own voluntarily or were invited by friends who had received care services, and $7 \%$ of the results were from the judicial operation process. Meanwhile, 37\% of respondents in LKS received services as a result of outreach, $16 \%$ referrals from community leaders, and $2 \%$ referrals from the local Social Service.

Table 7: Beneficiary motives for vagrancy

\begin{tabular}{ll}
\hline Vagrancy Motives & Percentage \\
\hline To earn living & $73 \%$ \\
No jobs in their hometown & $14 \%$ \\
To pay for childrens' education & $2 \%$ \\
Others & $11 \%$ \\
\hline
\end{tabular}

As for the reasons for vagrancy as scavengers, beggars, and buskers and abandoned on the streets, in general, is to earn a living (73\%), because they do not have a job at their hometown (14\%), other reasons $(11 \%)$, and $2 \%$ for their children's education. 
DOI: https://doi.org/10.47405/aswj.v6i6.192

Table 8: Average Beneficiary Earnings per Week

\begin{tabular}{lll}
\hline Per week & Earning & Expense \\
\hline$<100.000$ IDR & & \\
$(< \pm 7$ USD) & $22 \%$ & $13 \%$ \\
$100.000-300.000$ IDR (7-20 USD) & $57 \%$ & $56 \%$ \\
$300.000-700.000$ IDR (20-50 USD) & $18 \%$ & $26 \%$ \\
$>700.000$ IDR & & \\
$(>50$ USD) & $3 \%$ & $5 \%$ \\
\hline
\end{tabular}

This research shows that $57 \%$ of respondents have an average income per week of $100.000-300.000$ IDR or 7-20 USD and 56\% have an average expenditure of $100.000-300.000$ IDR Respondents whose income is between $300.000-700.000$ IDR or $20-50$ USD by $18 \%$. However, respondents whose expenses are between IDR $300.000-700.000$ represent a more significant number of $26 \%$.

Table 9: Savings and Debt of Beneficiaries

\begin{tabular}{lll}
\hline Possession & Savings & Debt \\
\hline No & $80 \%$ & $50 \%$ \\
Yes & $20 \%$ & $50 \%$ \\
\hline
\end{tabular}

This causes them to be vulnerable to being in debt, which is confirmed by data showing that respondents claim to have debts of $50 \%$.

This research also used a qualitative approach to deepen the quantitative findings. There are three important parts in the findings and discussion of this research; 1) social service institutions carry out the social rehabilitation services; 2) the level of social functioning of the beneficiaries, and 3) the role of social workers in social rehabilitation services carried out in the care and other social institutions.

\section{Social Rehabilitation Services}

In line with a study conducted by Sumantri et al. (2018), the implementation of guidance for vagrants and beggars includes services and rehabilitation. They are carried out through various spiritual, physical, social, mental, and skills guidance. This research shows differences in social rehabilitation services carried out by each institution.

There are different forms of service between the care institutions (Balai, Panti, and LKS). The rehabilitation services for vagrants and beggars in Balai and Panti are done in the form of residential, while LKS carries out the community approach. At least, social rehabilitation services at governmentowned institutions carry out stages starting from the initial approach to advanced coaching. Meanwhile, the service stage at LKS has not yet fully implemented the intended stage. At Technical Implementation Unit (UPT), physical, mental, social, spiritual, and skills guidance are carried out. The maximum service period is one fiscal year, as is done by several UPTs. There are also only a few months depending on the local government policy. Services at Pangudi Luhur as an institution that provides continued services are an on-and-off system. This means that termination can be carried out when the beneficiaries are considered independent, have sufficient skills to make a living, behave normatively, and overcome the problems they face.

Meanwhile, services at LKS can last for an indefinite time. The form of intervention given is highly dependent on the capabilities and capacities of each institution. Most of the respondents have not acquired sufficient skills, especially in most of the LKS. Social and psychological guidance at UPT, which is carried out by supervisors and partly by certified social workers, has not been able to optimally shape the mind and motivation of beneficiaries to survive in the face of post-service life. Skill training alone is not enough to change their behavior without entrepreneurship coaching. 
DOI: https://doi.org/10.47405/aswj.v6i6.192

In this case, it is important to support the social rehabilitation process for vagrants and beggars through several coaching models, including behavioral rehabilitation, work rehabilitation by increasing skills to become more productive, social-psychological rehabilitation, and educational rehabilitation to seek increased knowledge for beneficiaries (Putro, 2015).). However, the intervention or guidance at each institution is quite varied depending on the institution's condition. At the UPT, which carries out coaching in orphanages, physical guidance, mental, social, spiritual guidance, including skills guidance, is possible. While in LKS, not all guidance can be implemented, due to limited funding, infrastructure, including human resources.

\section{Level of Social Functioning}

Beneficiary's functional achievement is emulated from beneficiaries' ability before and after receiving assistance or services at the institution. The functional aspects include (1) the ability to fulfill basic needs, (2) the ability to execute a social role, (3) the ability to solve problems, and (4) the ability to be economically independent. Before entering the institution's ability to meet basic needs, beneficiaries usually rely on begging, scavenging junk, and busking around. After the beneficiaries receive institutional services, primarily those in the care institutions, they meet all basic needs. For beneficiaries outside the Panti (LKS), the fulfillment of basic needs still relies on activities of begging, scavenging, and singing. A study by Putro (2015), Social-psychological rehabilitation is part of the social rehabilitation process that tries as much as possible to restore psychological and social mental conditions to ensure their level of social functioning. Through this social rehabilitation, beneficiaries receive social and psychological support and economic assistance so that it is expected to be able to improve social functioning. One of them is evidenced by the beneficiary's statement at one of the Panti.

\footnotetext{
".....(I) do not want to do busking anymore because I am tired. It is better to help roadside vendors or be a parking attendant or dishwasher. The money I make, I give to my parents. If it was used for splurging such as drinking with fellow buskers in the past, it is now used for something more useful." (Informant CS)
}

This shows that the social rehabilitation process is very important to support this group of vagrants and beggars in improving their basic and social fulfillment abilities.

After receiving assistance, the ability to solve problems economically, socially, and psychologically, especially those in institutions, is facilitated to access institutions that suit their needs. They also have the opportunity to complain or ask for opinions from the Facilitator or LKS Officer, or Social Workers. The ability to be economically independent began to change gradually. If previously they supported themselves by begging or busking, after receiving the training, they could sell or work in other forms, but not all beneficiaries could be economically independent quickly. However, it is not necessarily the skill requirement available in social rehabilitation service institutions as expected by the beneficiary.

".......the Panti program is currently only agriculture, there is no skills training program. The Panti is only used as a place to find "capital" in the form of money that will be used later after leaving the Panti." (HNH informant)

The beneficiaries' independence is an important part of ensuring social functioning because selfreliance is related to tasks and skills in doing, achieving, and managing something (Parker, 2005).

\section{The Role of Social Workers in Social Rehabilitation Services}

Concerning human resources involved in social rehabilitation services, each institution has differences in the allocation and number of human resources. The results showed that the human resources between Balai/Panti and LKS had different compositions. This research shows that Social Workers and or those certified are mostly only present in government-owned institutions. As for the LKS, most of them employ social assistants or social worker graduates but have not been certified. 
DOI: https://doi.org/10.47405/aswj.v6i6.192

Table 10: Social Workers by Certification Status

\begin{tabular}{ll}
\hline Certification & Percentage \\
\hline Not certified & $60 \%$ \\
Certified & $40 \%$ \\
\hline
\end{tabular}

This research shows that $60 \%$ of social workers in Balai/Panti/LKS in the research locations have not obtained certification as social workers. In comparison, the other $40 \%$ have obtained certification as social workers.

Regarding capacity building, $65 \%$ of staff respondents at the institutes stated no training or guidance for the institutions' human resources. Only 35\% admitted that there were training or mentoring activities to increase the institutions' human resources capacity, as illustrated in the following figure.

Table 11: Training/Guidance from Institutions

\begin{tabular}{ll}
\hline Training & Percentage \\
\hline No & $65 \%$ \\
Yes & $35 \%$ \\
\hline
\end{tabular}

Another important aspect is how respondents get assistance when accessing a new job after leaving the Panti or LKS. The termination process must be sought for beneficiaries. However, assistance by officers to obtain new employment is also very necessary. There is still a lack of assistance for respondents by officers to access employment.

There is still a lack of skills or limited training for the social workers and assistants. For example, in South Sulawesi, facilitators were provided with training as mentors, but this activity was not on a regular basis. However, the role of assistants is at least quite helpful because they become a liaison if there are assisted residents who need health services and require population administration services. DKI Jakarta Province is also experiencing limited training for social workers and social workers in Panti. One of the social workers conveyed the limited role of social workers in handling vagrants and beggars.

\footnotetext{
"Social workers have not taken much part in handling PMKS vagrants and beggars. So far, we have prioritized programs such as the elderly, children and disabilities, so we have not focused on handling vagrant and beggar" (informant MR)
}

In carrying out their social services, social workers are faced with obstacles such as the difficulty of changing their behavior from life on the streets to a disciplined life in care institutions. This takes time and must be done repeatedly to become a daily habit pattern (e.g., self-cleaning behavior). Social workers also carry out further guidance. Social workers monitor the condition of the beneficiaries one month after the termination by monitoring the development, including their social life and independence. Are they able to continue running the business as agreed upon termination? What services are needed? Moreover, the obstacles faced by former beneficiaries. This will be used as evaluation material for the institution's services.

\section{Problems and Challenges in the Process of Social Rehabilitation Services}

i. Institutional issues including legal framework and investment: Dealing with the problem of vagrant beggars, there are still sectoral egos and overlapping authorities between the central and regional governments, both in the province and in the regency/municipal. There is still egocentrism between the central and local province and city/district governments in handling the social problems of this vagrant beggar group. In addition, there is still overlap regarding the authority of the central and regional governments, including the role of Balai as an advanced social rehabilitation service. There is still a gap between the authority of the central and regional governments, especially in direct services and the terms of coordination. 
ii. The problem of the intervention model: There are differences in social rehabilitation services carried out between the Balai/Panti and the LKS. Balai/Panti receive funding from the government and use a residential approach in their social rehabilitation services, starting with basic fulfilment, meeting social needs, and skills training. While in LKS, they focus more on social assistance.

iii. Program infrastructure issues including human resources preparedness: The number of officers is not proportional to the number of beneficiaries, and the service spaces are limited. Human resources for social workers and other professionals such as psychologists and skill counselors are also still lacking. In addition, skills and training for social workers and assistants are still inadequate. Through interviews to get more in-depth research, it was found that the obstacles faced were related to human resources, such as the example that occurred in one of the Balai.

"We at the Panti are experiencing problems regarding the number of workers, both social workers and social assistants. So often, officers do work that is not following their duties and functions. Plus the problem of limited instructors for training" (Informant C).

Research by Putro (2015) also shows the lack of facilities and infrastructure and inadequate human resources, while the supporting factor is cross-sectoral cooperation that supports the guidance process.

i. Cultural, political, and bureaucratic problems: Coordination and collaboration between institutions dealing with vagrant beggar is still limited. Developing coordination and collaboration of services between agencies in social rehabilitation services for the vagrant beggar group is a challenge in itself. This group has quite complex problems because they generally live on the move and in urban areas. As one of the marginal groups in urban areas, they often experience difficulties accessing education, health, and social assistance. However, coordination and collaboration between related agencies are still limited, hence the limitations of this group in accessing services.

ii. Sustainability Problems: The funds and budget for the process of mentoring and skills training, including for the follow-up of beneficiaries after rehabilitation are considerably very tight. The programs are not implemented continuously, depending on the political will of each province. For example, there is a tendency for programs at LKS and Panti to still depend on funds or instructions from the central government so that the programs cannot run continuously. If the program from the central government is completed, then the follow-up by the local government is less than optimal. Alternatively, vice versa, some programs in the regions have good results but lack guidance from the central government.

\section{Conclusion}

Vagrants and beggars have limited access to services. The process of social rehabilitation services for each institution is quite varied. In services at government owned Balai/Panti in general, the fulfillment of basic needs is well met because the government's budget supports it. However, social rehabilitation services at LKS still experience limited funds and human resources. Cooperation between the government, the community, the business community, and academia are vital. Access to social services must be opened to the vagrants and beggars to improve their social functioning.

\section{References}

Anggriana, T. M., \& Dewi, N. K. (2016). Identifikasi Permasalahan Gelandangan dan Pengemis di UPT Rehabilitasi Sosial Gelandangan dan Pengemis. INQUIRY: Jurnal Ilmiah Psikologi, 7(1).

Ahmad, M. (2010). Strategi Kelangsungan Hidup Gelandangan-Pengemis (Gepeng). Jurnal Penelitian, 7(2), 1-16.

Achlis. (1992) Pekerja sosial sebagai profesi dan praktek pertolongan. Bandung. STKS. 
DOI: https://doi.org/10.47405/aswj.v6i6.192

Bramley, G., Fitzpatrick, S., \& Sosenko, F. (2020). Mapping the "hard edges" of disadvantage in England: Adults involved in homelessness, substance misuse, and offending. The Geographical Journal, 186(4), 390-402.

Fahrudin, Adi (2012). Pengantar Kesejahteraan Sosial. Bandung: Refika Aditama.

Fitri, I. A. (2019). Penanggulangan Gelandangan Dan Pengemis Di Indonesia (Analisis Program Desaku Menanti di Kota Malang, Kota Padang dan Jeneponto). Share: Sosial Work Journal, 9(1), 1. https://doi.org/10.24198/share.v9i1.19652.

Husmiati, Kurniasari.A., Ruaida.M, Sumarno, S. Delfirman. (2020). Kompetensi Pekerja Sosial dalam Pelayanan Rehabilitasi Sosial di Balai / Loka Pada Era Tatanan Baru. Laporan Penelitian (tidak dipublikasikan). Puslitbangkesos Kemensos.

Kuntari, S., \& Hikmawati, E. (2017). Melacak Akar Permasalahan Gelandangan Pengemis (Gepeng). Media Informasi Penelitian Kesejahteraan Sosial, 41(No. 1), 11-26.

Mago, V. K., Morden, H. K., Fritz, C., Wu, T., Namazi, S., Geranmayeh, P., ... \& Dabbaghian, V. (2013). Analyzing the impact of sosial factors on homelessness: a Fuzzy Cognitive Map approach. BMC medical informatics and decision making, 13(1), 1-19.

Mujiyadi, Habibullah, Syawie, Amalia. (2014). Pencapaian Kinerja Utama Kementerian Sosial RI. Jakarta: Puslitbangkessos Kemensos.

Mason, J. (2002). Designing qualitative research. In Qualitative researching (2nd ed.) (pp. 24e48). Thousand Oaks, CA: Sage.

Nila, Hastuti, Larasati, Wahyu. (2020). Konsep Indeks Kesejahteraan Sosial: Dimensi dan Potensi Indikator Pembentuk. The SMERU Research Institute.

Nurdin.W. Husmiati, Alit K, Mulia A, Setyo S, Ruaida M. (2012). Evaluasi Pelaksanaan Rehabilitasi Sosial Pada Panti Sosial: Pembinaan Lanjut (After Care Services) Pasca Rehabilitasi Sosial. P3KS Press.

Lastiwi, D. T., \& Badruesham, N. (2017). Library for the homeless: A case study of a Shelter House and a School for Homeless in Indonesia and Malaysia.

Merlindha, A., \& Hati, G. (2015). Upaya Rehabilitasi Sosial dalam Penanganan Gelandangan dan Pengemis di Provinsi DKI Jakarta. Jurnal Ilmu Kesejahteraan Sosial, 16(1), 6073. https://doi.org/10.7454/jurnalkessos.v16i1.67

Sukoco. Dwi Heru (1991). Profesi pekerja sosial dan proses pertolongannya. STKS. Bandung. Syauqi. (2021). Asistensi Rehabiltasi Sosial. Jakarta: Biro Perencanaan Kementerian Sosial.

United Nations Children's Fund (2020). The State of Children in Indonesia - Trends, Opportunities and Challenges for Realizing Children's Rights. Jakarta: UNICEF Indonesia.

Undang-Undang Nomor 11 Tahun 2009 Tentang Kesejahteraan Sosial.

Undang-Undang Nomor 23 Tahun 2014 Tentang Pemerintahan Daerah.

Undang - Undang Nomor 14 Tahun 2019 Tentang Pekerja Sosial.

Waluyo, S. (2002). Proses rehabilitasi sosial gelandangan dan pengemis: Studi kasus di Panti Sosial Bina Karya "Pangudi Luhur" Bekasi (Tesis Perpustakaan Universitas Indonesia.

Zastrow. C. (1996). Introduction to social work and social welfare. Brooks/Cole Publishing.

Zastrow. C. (2020). Social work with groups : a comprehensive workbook. Thomson Brooks Cole. 